\title{
Scleredema associated with immunoglobulin A-K smoldering myeloma: a case report and review of the literature
}

\author{
B. S. D. P. Keragala, H. M. M. T. B. Herath*, G. H. D. C. Janappriya, B. S. Dissanayaka, S. C. Shyamini, D. P. Liyanagama, \\ Thanushah Balendran, S. R. Constantine and C. N. Gunasekera
}

\begin{abstract}
Background: Scleredema is a rare sclerodermoid skin condition characterized by diffuse symmetrical thickening of the upper part of the body. Its association with monoclonal gammopathy and myeloma was recently described; very few cases have been reported to date.

Case presentation: A 66-year-old Sri Lankan woman who had been followed in a dermatology unit for 34 years with diffuse systemic sclerosis presented with an acute exacerbation of the skin disease. Absence of Raynaud's phenomenon; sclerodactyly; characteristic lung, gastrointestinal, and cardiac involvement of systemic sclerosis; and repeatedly negative antinuclear antibodies test results led to reevaluation for the possibility of scleredema. Skin biopsies from four body sites showed normal epidermis and thickened reticular dermis with swollen collagen bundles separated from one another by clear spaces, resulting in fenestration. The skin appendages were not atrophied or bound down. Alcian blue staining showed interstitial mucin deposition. Serum protein electrophoresis demonstrated an abnormal monoclonal band in the $\beta$-region with a paraprotein level of $8.9 \mathrm{~g} / \mathrm{dl}$. Immunofixation showed an abnormal band in the $\gamma$-region consisting of immunoglobulin $A$ and $k$. Bone marrow biopsy revealed abnormal monoclonal plasma cells (15\%) with multinuclearity. There was no evidence of end organ damage, and whole-body magnetic resonance imaging did not reveal any evidence of bone involvement. The patient's diagnosis was revised as scleredema type 2 associated with lgA-k, and she was referred to a hemato-oncologist for chemotherapy, which led to significant improvement in the skin condition.
\end{abstract}

Conclusions: Scleredema is a rare disorder that has an enigmatic, rare association with monoclonal gammopathy. Dermatologists should be aware of this rare but important association.

Keywords: Scleredema, Smoldering myeloma, Monoclonal gammopathy

\section{Introduction}

Scleredema is rare sclerodermoid skin disease characterized by symmetrical diffuse woody induration of the upper part of the body owing to thickened dermis and excessive dermal mucin deposition. Though the commonest association of it is diabetes mellitus (type 3) [1], scleredema has been reported to occur with a history of an antecedent infection (type 1) and many other systemic diseases. Of them, monoclonal gammopathy was a recently described unusual association (type 2) with unknown significance. A high degree of suspicion is needed

\footnotetext{
* Correspondence: tharukaherath111@gmail.com

National Hospital of Sri Lanka, Colombo, Sri Lanka
}

to differentiate scleredema from scleroderma when scleredema has a chronic course with generalized involvement. Owing to the rarity of the disease and subtle differences in the skin manifestation, histopathological assessment with mucin staining is invaluable in doubtful instances.

We report a case of a patient with long-standing widespread scleredema associated with immunoglobulin A-k smoldering myeloma, which was misdiagnosed as scleroderma for many years. Only a few case reports are available in the literature on scleredema associated with myeloma; to the best of our knowledge, this is the first patient to be

(c) The Author(s). 2019 Open Access This article is distributed under the terms of the Creative Commons Attribution 4.0 International License (http://creativecommons.org/licenses/by/4.0/), which permits unrestricted use, distribution, and 
reported with scleredema who was diagnosed with smoldering myeloma of IgA-k. This case report highlights the importance of awareness of scleredema because it is rare and can be misdiagnosed and, if diagnosed, it can be treated. We also include a detailed literature review.

\section{Case presentation}

A 66-year-old Sri Lankan woman who had been followed in a dermatology unit for 34 years for diffuse systemic sclerosis presented to our institution with an acute exacerbation of the skin disease. She was treated with corticosteroids and cyclophosphamide pulses and subsequently with mycophenolate mofetil for the skin condition. She did not have any other past medical or family history of systemic diseases, chronic infections, malignancies, or genetic diseases. She was a housewife, was unemployed, and was not exposed to any indoor or outdoor toxins, chemicals, or radiation. She was a nonsmoker and nonalcoholic.

On examination, she had widespread thickening of the skin predominantly involving the trunk and proximal extremities (Fig. 1). She did not have sclerodactyly, but she had deformities in keeping with osteoarthritis (Fig. 2). She denied cold-induced episodic acral bluish discoloration suggestive of Raynaud's phenomenon. She was not febrile, and the result of her general examination was normal without pallor, cyanosis, clubbing, lymphadenopathy, or bilateral ankle edema. Her respiratory and cardiovascular examination results were normal with a heart rate of 82 beats per minute and a blood pressure of $130 / 80 \mathrm{mmHg}$. The result of her neurological examination was normal with normal

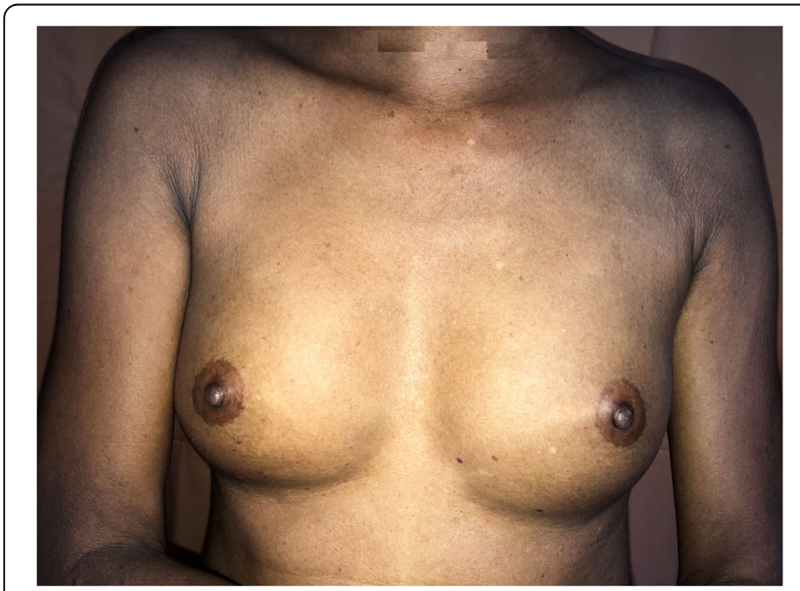

Fig. 1 Widespread thickening of the skin predominantly involving the trunk and proximal extremities

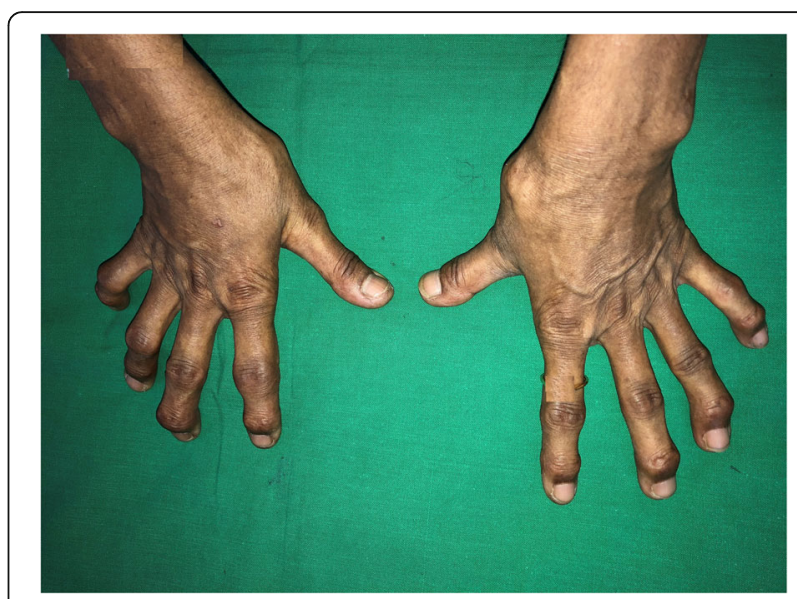

Fig. 2 The patient did not have sclerodactyly but had deformities in keeping with osteoarthritis

funduscopy without any cranial neuropathy or peripheral neuropathy. Repeated echocardiography did not reveal any evidence of pulmonary hypertension. Upper gastroduodenoscopy did not show reflux disease. Radiographically, there was no evidence of interstitial lung disease. The patient's autoimmune antibody profile (antinuclear antibody, anti-doublestranded DNA, perinuclear antineutrophil

Table 1 Full blood count, liver function test, and serum electrolyte results

\begin{tabular}{llll}
\hline Investigation & Value & Normal range & Comment \\
\hline WBC & $9.32 \times 10^{3} / \mu \mathrm{l}$ & $4-10$ & Normal \\
Lymphocytes & $2.17 \times 10^{3} / \mu \mathrm{l}$ & $0.8-4$ & Normal \\
Serum creatinine & $0.9 \mathrm{mg} / \mathrm{dl}$ & $60-120$ & Normal \\
Serum potassium & $3.4 \mathrm{mmol} / \mathrm{L}$ & $3.5-5.1$ & Normal \\
AST & $27 \mathrm{U} / \mathrm{L}$ & $10-35$ & Normal \\
Albumin & $38 \mathrm{~g} / \mathrm{L}$ & $35-45$ & \\
Alkaline phosphatase & $104 \mathrm{U} / \mathrm{L}$ & $100-360$ & Normal \\
lonized calcium & $1.21 \mathrm{mmol} / \mathrm{L}$ & $1.0-1.3$ & Normal \\
Amylase & $68 \mathrm{U} / \mathrm{L}$ & $22-80$ & Normal \\
Neutrophils & $6.09 \times 10^{3} / \mu \mathrm{l}$ & $2-7$ & Normal \\
Platelets & $277 \times 10^{3} / \mu \mathrm{l}$ & $150-450$ & Normal \\
Serum sodium & $138 \mathrm{mmol} / \mathrm{L}$ & $135-148$ & Normal \\
& & & Normal \\
ALT & $20 \mathrm{U} / \mathrm{L}$ & $10-40$ & Normal \\
INR & 1.26 & & Normal \\
Serum magnesium & $1.7 \mathrm{mg} / \mathrm{dl}$ & $1.7-2.7$ & Normal \\
Troponin I & $<0.1 \mathrm{ng} / \mathrm{ml}$ & $<0.5$ & Normal \\
\hline Abbrevations: $A T T A a n i n$ & aming
\end{tabular}

Abbreviations: ALT Alanine aminotransferase, AST Aspartate aminotransferase, INR International normalized ratio, WBC White blood cells 
cytoplasmic antibodies, cytoplasmic antineutrophil cytoplasmic antibodies, anti-Smith antibody, anti RO and anti-LA, antitopoisomerase antibody, anticentromere antibody, and complements) was persistently negative, and her full blood count, urine full report, and renal and liver function were normal (Table 1). Absence of Raynaud's phenomenon; sclerodactyly; characteristic lung, gastrointestinal, and cardiac involvement of systemic sclerosis; and repeatedly negative antinuclear antibody test results lead us to reevaluate the patient for the possibility of scleredema.

Skin biopsies from four body sites showed normal epidermis and thickened reticular dermis with swollen collagen bundles separated from one another by clear spaces, resulting in fenestration. The skin appendages were not atrophied or bound down.
Alcian blue staining showed interstitial mucin deposition suggestive of scleredema. Serum protein electrophoresis demonstrated an abnormal monoclonal band in the gamma region with a paraprotein level of $8.9 \mathrm{~g} / \mathrm{dl}$. Immunofixation showed an abnormal band in the gamma region consisting of IgA and $\kappa$. Bone marrow biopsy revealed abnormal monoclonal plasma cells (15\%) with multinuclearity. There was no evidence of end organ damage with normal calcium, renal function, and full blood count, and whole-body magnetic resonance imaging did not reveal any evidence of bone involvement (Fig. 3). The patient's diagnosis was revised as scleredema type 2 associated with IgA-k smoldering myeloma. She was commenced on intravenous immunoglobulin (IVIG) monthly ( $1 \mathrm{~g} / \mathrm{kg}$ for 2 days per month), and a hemato-oncologist started

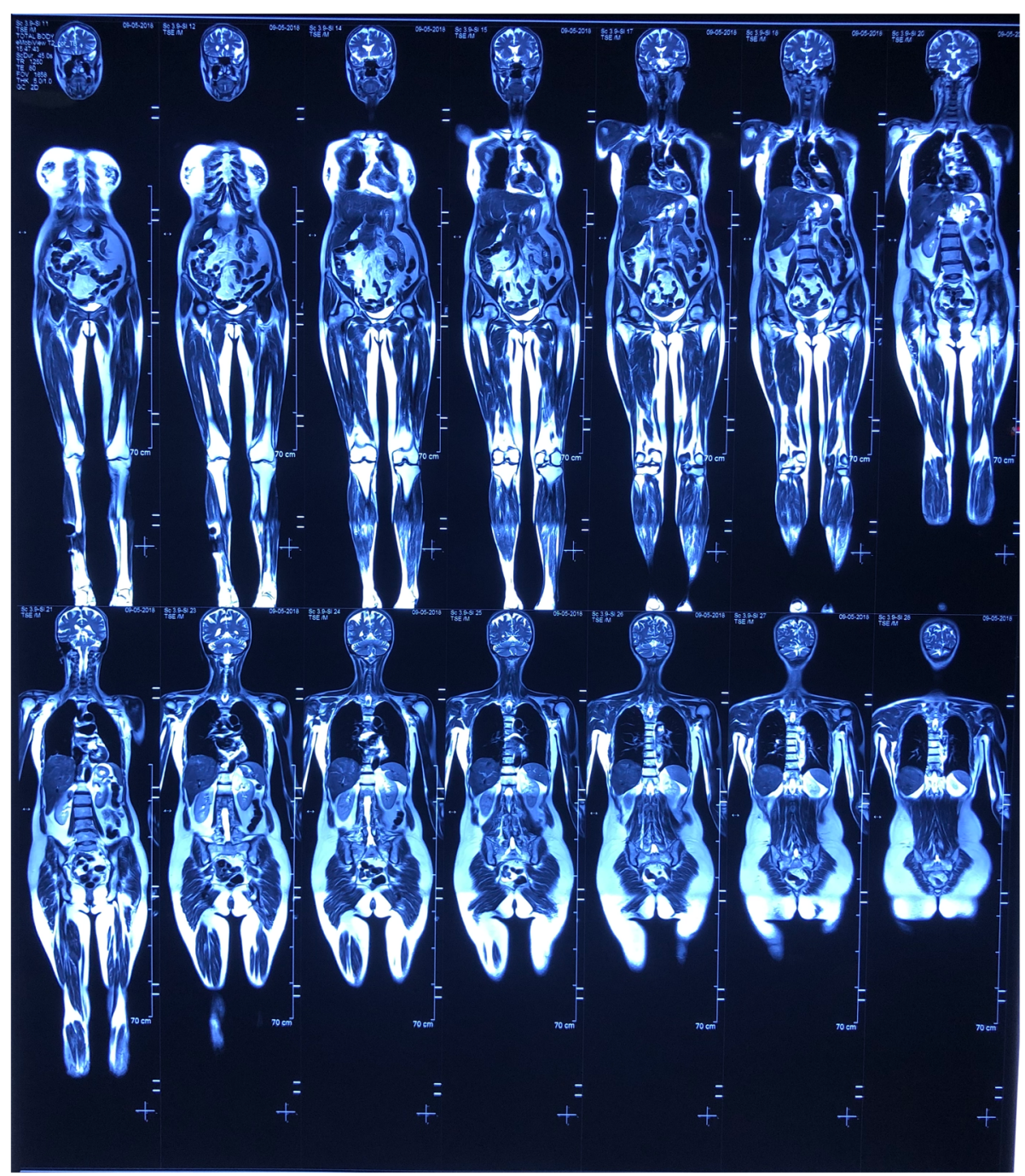

Fig. 3 Normal whole-body magnetic resonance imaging 
intravenous bortezomib cycles (1.7 $\mathrm{g}$ on day 1 , day 8 , day 22, and day 29). Currently, she was receiving 6 months of IVIG and four cycles of intravenous bortezomib, and significant improvement of the skin was observed.

\section{Discussion}

In this report, we present a case of a patient with widespread thickening of the skin predominantly involving the trunk and proximal extremities for more than 30 years who was misdiagnosed with systemic sclerosis. Absence of Raynaud's phenomenon; sclerodactyly; characteristic lung, gastrointestinal, and cardiac involvement of systemic sclerosis; and repeatedly negative antinuclear antibody test results led to reevaluation of the diagnosis. Later she was diagnosed with scleredema with smoldering myeloma, and she responded well to treatment.

In keeping with the literature, even though scleredema with monoclonal gammopathy is reported, multiple myeloma (MM)-associated scleredema is rare. In 1974, Korting et al. reported one patient with MM; in 1984, Venencie et al. reported one patient with smoldering myeloma; and in 1987, Ohta et al. reported one patient with MM [2-4]. After that, several case reports were reported (Table 2). Seven were male patients, six were female, and the majority were above the age of 50 . Interestingly, one patient was in his 20s [5]. Only two patients were reported with smoldering myeloma (one with $\operatorname{IgG}-\kappa$ and the other with $\operatorname{IgG}-\lambda$ ) and scleredema $[2,6]$ in the literature, and all the others had MM (five with IgG-K, four with IgA-k, one with IgG- $\lambda$, and one with IgA- $\lambda$; two had IgG and the light chain was not mentioned). This shows that the number of patients with IgG and IgA were observed in almost equal numbers and that the majority of patients had $\mathrm{k}$-light chains compared with $\lambda$-light chains (10 patients with $\mathrm{k}$, 3 patients with lambda). Even in scleredema associated with monoclonal gammopathy without MM, IgG-K predominates (10 of 23 cases in one review) [7]. Our patient is the first to be reported with scleredema who was diagnosed with smoldering myeloma of IgA-k.

The diffuse woody induration described in almost all the cases in the literature involved the face, neck, back, shoulders, chest, and upper arm. Similar to our patient, all the patients had skin manifestations for a long time before the diagnosis of myeloma, except in one case where the skin changes appeared while the patient was receiving treatment for myeloma [8]. As in our patient, none of the patients in the literature had Raynaud's phenomenon; sclerodactyly; or characteristic lung, gastrointestinal, or cardiac involvement of systemic sclerosis, which is important to differentiate from systemic sclerosis. One case report described a patient with MM and scleredema who developed cardiomyopathy. Deposition of acid mucopolysaccharide in the heart is proposed as the mechanism for this scleredema cardiomyopathy [9]. Acanthosis nigricans [10] and myelofibrosis [5] are also described in patients with scleredema and MM.

The possible pathology of monoclonal gammopathy and scleredema is still not clear. Kovary et al. suggested that paraproteins may function as antibodies directed against connective tissues, but monoclonal immunoglobulins were not detected in the skin by direct immunofluorescence microscopy [11]. This is in contrast to scleromyxedema (lichen myxedematosus), from which scleredema can be distinguished clinically and histologically [11]. Ohta et al. showed that serum from patients with scleredema stimulates collagen production in normal skin fibroblast cultures, collagen production in autologous cell cultures, and sulfate incorporation into fibroblasts [4]. They suggested that circulating serum factors in these patients, possibly related to the paraproteins, may stimulate the synthesis of extracellular macromolecules by dermal fibroblasts, leading to dermal fibrosis. On the basis of these studies, we can postulate that immunological factors may play a role in the pathogenesis of scleredema.

Interestingly, all the patients in the literature showed improvement of the skin condition with therapy. Different chemotherapy regimens, including melphalan, cyclophosphamide, vincristine, and thalidomide combined with steroids, were used in these cases (Table 1). A bortezomib-based regimen has also shown a convincing response [12, 13]. In the two case reports with scleredema associated with smoldering myeloma, we were unable to find any specific therapy given for the skin condition. However, IVIG has shown significant skin condition improvement in two patients with scleredema [13]. Grudeva-Popova and Dobrev suggested that noninvasive skin elasticity measurements can be used to assess improvement after treatment [8].

\section{Conclusions}

We highlight that scleredema should be considered in the differential diagnosis of patients with diffuse skin thickening without characteristic features of systemic sclerosis. In these patients, it is also important to investigate for monoclonal gammopathy and myeloma. Even if 


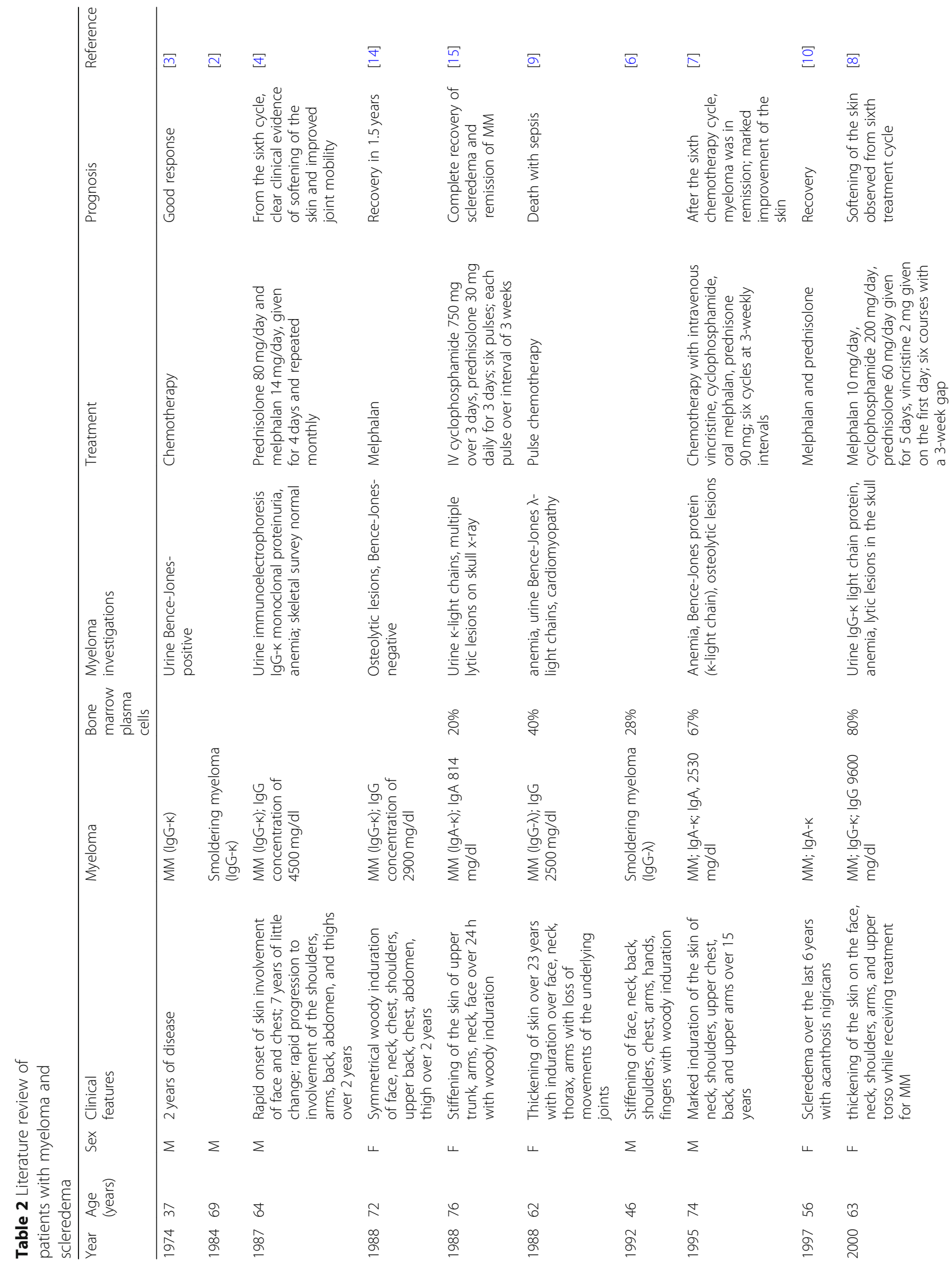




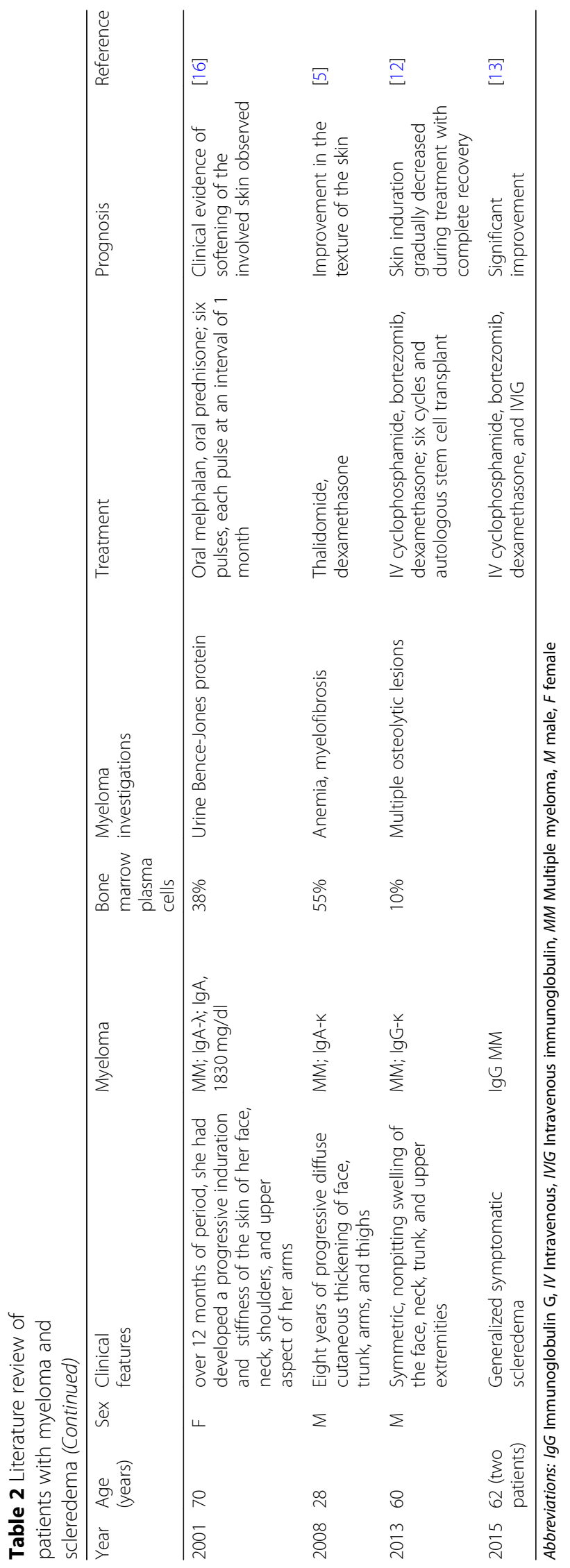


the initial screening result is negative, serum protein electrophoresis should be performed at regular intervals because paraproteinemia may appear later and, when present, may progress to myeloma. This case report and others in the literature show that this condition is treatable with significant improvement of the skin condition.

\section{Abbreviations}

ALT: Alanine aminotransferase; AST: Aspartate aminotransferase; IgG: Immunoglobulin G; INR: International normalized ratio; IV: Intravenous; IVIG: Intravenous immunoglobulin; MM: Multiple myeloma; WBC: White blood cells

\section{Acknowledgements}

None to declare.

\section{Funding}

No source of funding.

\section{Availability of data and materials}

The datasets supporting the conclusions of this article are included within the article.

\section{Authors' contributions}

BSDPK and HMMTBH did the literature survey and prepared the main manuscript. BSDPK, GHDCJ, BSD, DPL, TB, and CNG were involved in the diagnosis and management of the patient. SCS and SRC assisted in the histopathological diagnosis. SRC and CNG did the proofreading and correction of the manuscript. All authors read and approved the final manuscript.

\section{Ethics approval and consent to participate}

Not applicable.

\section{Consent for publication}

Written informed consent was obtained from the patient for publication of this case report and any accompanying images. A copy of the written consent is available for review by the Editor-in-Chief of this journal.

\section{Competing interests}

The authors declare that they have no competing interests.

\section{Publisher's Note}

Springer Nature remains neutral with regard to jurisdictional claims in published maps and institutional affiliations.

Received: 23 October 2018 Accepted: 4 April 2019

Published online: 14 May 2019

\section{References}

1. Rongioletti F, Kaiser F, Cinotti E, Metze D, Battistella M, Calzavara-Pinton PG, Damevska K, Girolomoni G, Andre J, Perrot JL, et al. Scleredema: a multicentre study of characteristics, comorbidities, course and therapy in 44 patients. J Eur Acad Dermatol Venereol. 2015;29(12):2399-404.

2. Venencie PY, Powell FC, Su WP. Scleredema and monoclonal gammopathy: report of two cases. Acta Derm Venereol. 1984;64(6):554-6.

3. Korting GW, Gilfrich HJ, Meyer zum Büschenfelde KH. Scleredema adultorum and multiple myeloma [in German]. Arch Dermatol Forsch. 1974;248(4):379-85.

4. Ohta A, Uitto J, Oikarinen Al, Palatsi R, Mitrane M, Bancila EA, Seibold JR, Kim HC. Paraproteinemia in patients with scleredema: clinical findings and serum effects on skin fibroblasts in vitro. J Am Acad Dermatol. 1987:16(1 Pt 1):96-107.

5. Rao S, Kar R, Pati HP, Saxena R. Scleredema-associated IgA myeloma with myelofibrosis in a young adult: a case report. Turk J Haematol. 2008;25(4): 195-7.

6. Schmidt KT, Gattuso P, Messmore H, Shrit MA, Massa M, Welykyj S. Scleredema and smoldering myeloma. J Am Acad Dermatol. 1992;26(2 Pt 2): 319-21.
7. Pujol JA, Bueno M, Fuertes MA, Gimenez H, Carapeto FJ. Improvement of scleredema associated with lgA multiple myeloma after chemotherapy. Clin Exp Dermatol. 1995;20(2):149-52.

8. Grudeva-Popova J, Dobrev H. Biomechanical measurement of skin distensibility in scleredema of Buschke associated with multiple myeloma. Clin Exp Dermatol. 2000;25(3):247-9.

9. Rimon D, Lurie M, Storch S, Halon D, Eisenkraft S, Laor A, Cohen L. Cardiomyopathy and multiple myeloma: complications of scleredema adultorum. Arch Intern Med. 1988:148(3):551-3.

10. Valente L, Velho GC, Farinha F, Bernardo A, Ribeiro P, Massa A. Scleredema, acanthosis nigricans and lgA/K multiple myeloma [in French]. Ann Dermato Venereol. 1997;124(8):537-9.

11. Kovary PM, Vakilzadeh F, Macher E, Zaun H, Merk H, Goerz G. Monoclonal gammopathy in scleredema: observations in three cases. Arch Dermatol. 1981:117(9):536-9.

12. Szturz P, Adam Z, Vasku V, Feit J, Krejci M, Pour L, Hajek R, Mayer J. Complete remission of multiple myeloma associated scleredema after bortezomib-based treatment. Leuk Lymphoma. 2013;54(6):1324-6.

13. Krejci M, Adam Z, Pour L, Michalkova E, Sandecka V, Szturz P, Kral Z, Mayer J. Scleredema associated with multiple myeloma or MGUS: treatment report of four cases [abstract]. Clin Lymphoma Myeloma Leukemia. 2015;15(Suppl 3):e207.

14. Hodak E, Tamir R, David M, Hart M, Sandbank M, Pick A. Scleredema adultorum associated with lgG-k multiple myeloma - a case report and review of the literature. Clin Exp Dermatol. 1988;13(4):271-4.

15. Salisbury JA, Shallcross H, Leigh IM. Scleredema of Buschke associated with multiple myeloma. Clin Exp Dermatol. 1988;13(4):269-70.

16. Santos-Juanes J, Osuna CG, Iglesias JR, De Quiros JF, del Rio JS. Treatment with chemotherapy of scleredema associated with IgA myeloma. Int $J$ Dermatol. 2001;40(11):720-1.
Ready to submit your research? Choose BMC and benefit from:

- fast, convenient online submission

- thorough peer review by experienced researchers in your field

- rapid publication on acceptance

- support for research data, including large and complex data types

- gold Open Access which fosters wider collaboration and increased citations

- maximum visibility for your research: over $100 \mathrm{M}$ website views per year

At $\mathrm{BMC}$, research is always in progress.

Learn more biomedcentral.com/submissions 